\title{
EFFECT OF SEASON AND SEX ON SOME PRODUCTIVE TRAITS OF PEKIN DUCK REARD INTESIVELY UNDER IRAQI CONDITIONS
}
A.J.SH.AL-Ghabban
Researcher
D.H.AL-Hassani
Prof.

Dept. Anim. Prod., Coll. Agric. Engin. Sci., University of Baghdad, Iraq

Ahmed.algabban79@gmail.com

alhassani.dihya@ Yahoo.com

\section{ABSTRACT}

This study was conducted at Poultry farm/Department of Animal Production/College of Agricultural Engineering Sciences/University of Baghdad, were divided into two experiments one during summer and second during winter seasons to study the effect of season and sex on productive performance of Pekin duck reared in an intensive system under harsh Iraqi conditions. A hundred fifty, one day old ducklings were used in each experiment. On 14 day of age, birds were sexed then randomly divided into nine replicates (pens) (5 replicates for females and 4 for males). Results indicated that season has significant effects on studied traits. Body weight, weight gain and food consumption were significantly $(p<0.01)$ higher in birds reared in winter than those reared in summer, whereas no significant differences existed in feed conversion ratio and mortality. Males revealed highly significant ( $p<0.01$ ) in body weight and weight gain compared with females in both seasons. Study revealed that pekin duck performance were slightly effected and resisted to acute high temperature during summer. Pursuant to, it can be reared pekin duck in intensive system throughout year in Iraq.

Key words: bird, summer, winter, body weight, weight gain, six.

الغبان والحسني

123-116:5جلة العلوم الزراعية العراقية -51:2020(عدد خاص)

تأثير الموسم والجنس على بعض الصفات الانتاجية للبط البكيني المربى بنظام التربية المكثفة في ظروف العراق

$$
\text { احمد جاسم شاكر الغبان }
$$

المستخلص

تم أجراء الدراسة في حقل الدواجن التابع لقسم الانتاج الحيواني، كلية علوم الهندسة الزراعية، جامعة بغداد. إذ قسمت الى تجريتين نقذت التجرية الاولى خلال فصل الصيف والثانية خلال فصل الثتاء وذلك لدراسة تأثير الموسم والجنس على الاداء الانتاجي للبط البكيني المربى تربية مكثفة في الظروف المناخية العراقية القاسية. استخدم مئة وخمسون من افراخ البط بعر يوم واحد لكل تجرية قسمت الى تسع مكررات (كن) بعد ان تم تجنيسها بعمر 14 يوم (5 مكررات للإناث ، 4 مكررات للأكور).

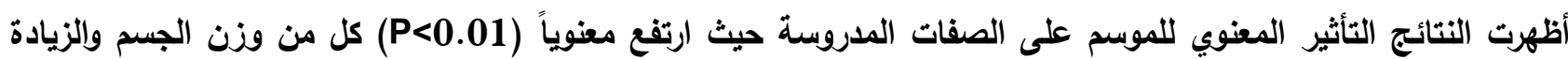
الوزنية واستهلاك العلف للطيور المرباة في فصل الثتاء مقارنةً بالصيف، في حين لم تظهر فروقات معنوية في معامل التحويل

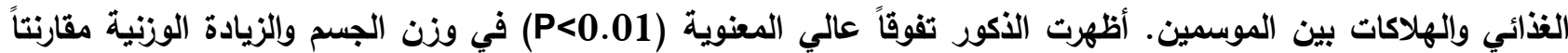
بالاناث في كلا الموسمين. بينت الدراسة التأثر الذفيف في اداء البط البكيني ومقاومته العالية لارتفاع درجات الحرارة الثديد خلال فصل الصيف. ويناءً على ذلك يمكن تربية البط البكيني في نظام التربية المكثفة طوال السنة في العراق. الكلمات المفتاحية : طيور، الصيف، الثتاء، وزن الجسم، الزيادة الوزنية، الجنس. 


\section{INTRODUCTION}

Poultry industry is considered one of important economical sectors that involves in food security by ensuring global needs of meat and egg (13), which represents the major source of animal protein in many countries around the world (20). High environmental temperature in a different countries such Iraq is considered the most serious problem facing poultry production $(19,3)$. In domestic birds, high temperature above thermoneutral zone leads to decrease in feed intake, body weight and weight gain $(15,4)$, an increase in water intake and mortality $(9,5)$, deterioration in feed conversion, reduction in performance and physiological functions (14,17)and finally inhibits immunity (1). Duck is waterfowl bird that domesticated since four thousands year in Asia, where the majority are reared according its convenient to the environment and used for human consumption (22). There are many pure breeds of duck classified into meat, egg and both production, Pekin duck still is the predominant among them (24). Duck is characterized with high resistance to common diseases that infect other poultry and are tolerant to harsh conditions (11), beside to its meat has high nutrient value (25). As a result of that global duck production and consumption were increased during last five decades (13). Since along time Iraqi people used to rear and consume local Iraqi duck, which characterized with low productivity and mostly existing in rural areas. Modern duck breeds such as Pekin duck were recently entered Iraq, and farmers started rearing it in an open system with small number of birds. There are a few studies concerning with rearing duck in controlled intensive system under high temperature (2), in addition there is no such studies were conducted in Iraq, thus this study has been done.

\section{MATERIALS AND METHODS}

This study was conducted at the Poultry farm, Department of Animal Production, College of Agricultural Engineering Sciences, University of Baghdad, included two experiments performed, the first one during summer and the second during winter. Hundred fifty one day old Pekin ducklings breed were used for each experiment, reared for 49 days . Birds were purchased from local private hatchery.
Initial body weight of day old were $49.6 \mathrm{~g}$ and $41.5 \mathrm{~g}$ for first and second experiments respectively. All birds were divided randomly into pens $(1.5 \times 2 \mathrm{~m})$ with 25 birds in each. Birds were reared on $3-5 \mathrm{~cm}$ thickness sawdust litter for the first two weeks of age, after that birds were sexed, then each sex was randomly distributed into pens ( 5 replicates for females and 4 for males) with 16-17 birds each and 5-6 birds/ $\mathrm{m}^{2}$ density. Birds were accessed freely to water and feed. House temperature and humidity were recorded by digital $\mathrm{TCH}-4$ device, china company (Table 1 and 2 ). Starter and grower rations of mash diet were introduced to birds (Table 3). Air cooler was used during summer and gas heater during winter to get required temperatures. Lighting system was $23 \mathrm{~h}$ light and $1 \mathrm{~h}$ dark daily. All data were statistically analyzed (23).

\section{RESULTS AND DISCUSION}

Tables 4 and 5 indicate a significant $(\mathrm{P}<$ 0.01 ) increases in live body weight and weight gain at 7 and 14 days of age for birds reared in summer in comparison to that reared in winter, whereas inversely happened at 21, 28, 35 and 42 days and for the total period (1-42 days). Sex revealed its effects on body weight and weight gain in summer and winter, since males had higher body weight than female at 14, 21, $28,35,42$ and 49 days of age, excluding 28 and 35 days exhibited no significant differences between sex in winter ( Table 6,7). Weight gain response to sex had nearly the same trend with lower differences between sex ( Table 7 ). In comparison with winter, birds reared in summer revealed a significant $(\mathrm{P}<$ 0.01) decrease in feed consumption at all periods recorded, unless 1-7 days period ( Table 8 ). Season had no significant effect on feed conversion ratio, excepting 15-21 days period which indicated a significant deterioration in summer with counterpart in winter ( Table 9 ). No significant differences in mortality between birds of both seasons (winter and summer), which had the same percentage $(3.3 \%$ ) ( Figure 1 ). The high live body weight and weight gain at 7 and 14 days of age in summer could be due to the differences between the initial body weight for ducklings, which was $49.6 \mathrm{~g}$ and $41.5 \mathrm{~g}$ in summer and winter respectively. (18) and (6) mentioned that initial body weight has 
significant $(\mathrm{P}<0.01)$ effect on body weight of ducklings and broiler chicks at 1 and 2 week of age, then the differences started to diminish with advancing in age. The significant improvement in body weight, weight gain and feed conversion ratio mainly concerned to increase of feed intake, which a result of decrease in temperature during winter. On the contrary high summer temperature played crucial role in decrease feed intake, that negatively effect on body weight, weight gain and deterioration of feed consumption ratio. It is well known that heat stress causes wide damages in physiological functions then performance in poultry, such as increase body temperature and mortality (16), inhibits appetite followed by feed intake decrease (19), decrease of body weight and weight gain and deterioration of feed consumption ration $(7,8)$ and finally decrease immunity against diseases (12). In general, previous studies already revealed the effects of sex on body weight, feed intake, mortality and heat tolerance in poultry, which is mostly in favor of males (10).

Table 1. Mean temperatures and relative humidity inside rearing duck house

during summer season

\begin{tabular}{|c|c|c|c|c|c|c|}
\hline \multirow{2}{*}{$\begin{array}{c}\text { Age } \\
\text { (week) }\end{array}$} & \multicolumn{3}{|c|}{ Temperature $\left({ }^{\circ} \mathrm{C}\right)$} & \multicolumn{3}{|c|}{ Relative Humidity (\%) } \\
\hline & Minimum & Maximum & Mean & Minimum & Maximum & Mean \\
\hline 1 & 27.9 & 36.8 & 32.3 & 35.3 & 64.1 & 45.3 \\
\hline 2 & 29.8 & 39.7 & 33.5 & 24.3 & 51.2 & 42.9 \\
\hline 3 & 30.1 & 38.2 & 33.5 & 36.5 & 55.3 & 45.8 \\
\hline 4 & 27.1 & 38.6 & 33.0 & 30.4 & 53.6 & 41.7 \\
\hline 5 & 29.0 & 41.5 & 33.6 & 26.4 & 51.9 & 39.2 \\
\hline 6 & 28.8 & 38.4 & 34.0 & 31.7 & 53.4 & 40.8 \\
\hline 7 & 24.5 & 35.3 & 29.1 & 33.8 & 63.2 & 47.4 \\
\hline
\end{tabular}

Table 2. Mean temperatures and relative humidity inside rearing duck house during winter season

\begin{tabular}{|c|c|c|c|c|c|c|}
\hline \multirow{2}{*}{$\begin{array}{c}\text { Age } \\
\text { (week) }\end{array}$} & \multicolumn{3}{|c|}{ Temperature $\left({ }^{\circ} \mathrm{C}\right)$} & \multicolumn{3}{|c|}{ (\%)relative humidity } \\
\hline & Minimum & Maximum & Mean & Minimum & Maximum & Mean \\
\hline 1 & 22.1 & 36.4 & 29.0 & 32.8 & 76.3 & 45.3 \\
\hline 2 & 20.2 & 36.0 & 26.0 & 36.7 & 76.3 & 54.5 \\
\hline 3 & 19.0 & 34.0 & 24.2 & 45.0 & 75.0 & 60.0 \\
\hline 4 & 18.5 & 28.0 & 23.1 & 47.3 & 74.1 & 59.6 \\
\hline 5 & 18.4 & 28.1 & 23.0 & 35.0 & 62.8 & 43.3 \\
\hline 6 & 14.7 & 29.5 & 23.1 & 30.5 & 69.1 & 49.0 \\
\hline 7 & 14.4 & 29.6 & 20.0 & 37.6 & 71.6 & 51.9 \\
\hline
\end{tabular}

Table 3.Composition and calculated analysis of experimental diets $f$ or the starter and finisher rations

\begin{tabular}{|c|c|c|}
\hline Ingredients (\%) & $\begin{array}{c}\text { Starter } \\
\text { (1-14 days) }\end{array}$ & $\begin{array}{c}\text { Finisher } \\
\text { (15-49 days) }\end{array}$ \\
\hline Wheat & 30.4 & 41.1 \\
\hline Corn(maize) & 34.0 & 40.0 \\
\hline Soybean meal ( $48 \%$ protein) & 28.5 & 12.55 \\
\hline Protein concentrate $^{1}$ & 5.0 & 5.0 \\
\hline Calcitic limestone & 0.6 & 0.7 \\
\hline Di-calcium phosphate & 0.5 & 0.25 \\
\hline Oil & 0.6 & - \\
\hline $\mathrm{NaCl}$ & 0.2 & 0.2 \\
\hline Vitamin and mineral premixes ${ }^{2}$ & 0.2 & 0.2 \\
\hline Total & 100 & 100 \\
\hline \multicolumn{3}{|l|}{ Calculated analysis ${ }^{3}$} \\
\hline Crude protein $(\%)$ & 22 & 16.15 \\
\hline Metabolizable energy (kcal/kg) & 2940.37 & 3033.89 \\
\hline Calcium (\%) & 0.68 & 0.63 \\
\hline Available phosphorus (\%) & 0.41 & 0.34 \\
\hline Methionine (\%) & 0.48 & 0.4 \\
\hline Lysine (\%) & 1.2 & 0.79 \\
\hline Cystine (\%) & 0.35 & 0.27 \\
\hline
\end{tabular}

${ }^{1}$ Each1 $1 \mathrm{~kg}$ of Protein concentrate contains protein $40 \%$, fat $5 \%$, fiber $2.2 \%$, moisture $7.13 \%$, calcium 4.2 , phosphorus $4.68 \%$, lysine $3.85 \%$, methionine $3.7 \%$, methionine plus cystine $4.12 \%$, metabolizable energy 2017 kcal and antioxidant $900 \mathrm{mg}$. ${ }^{2}$ Each $1 \mathrm{~kg}$ of vitamin and mineral premixes contains vitamins A $500 \mathrm{IU}, \mathrm{D}_{3} 600 \mathrm{IU}$, E $10 \mathrm{mg}, B_{1} 3 \mathrm{mg}, B_{2} 2 \mathrm{mg}, B_{6} 2 \mathrm{mg}, B_{12} 5 \mathrm{mg}, C 10 \mathrm{mg}$, niacin $15 \mathrm{mg}$ and folic acid $500 \mu \mathrm{gg} .{ }^{3}$ according to (21) 
Table 4. Effect of season on weekly mean live body weight (g) for both sexes of Pekin Duck (mean \pm standard error)

\begin{tabular}{|cccccccc|}
\hline Age (day) & \multicolumn{5}{c|}{ mean live body weight (g/bird) } & $\begin{array}{c}\text { Significant } \\
\text { Summer }\end{array}$ \\
\hline 7 & $\mathbf{2 1 0 . 0 9}$ & \pm & $\mathbf{2 . 1 3}$ & $\mathbf{1 8 8 . 7 5}$ & \pm & 1.98 & $* *$ \\
14 & $\mathbf{5 9 5 . 8 7}$ & \pm & $\mathbf{5 . 7 0}$ & $\mathbf{5 2 8 . 5 7}$ & \pm & $\mathbf{5 . 7 8}$ & $* *$ \\
21 & $\mathbf{9 4 9 . 4 6}$ & \pm & $\mathbf{6 . 8 6}$ & $\mathbf{1 0 4 3 . 7 3}$ & \pm & $\mathbf{7 . 2 5}$ & $* *$ \\
28 & 1358.22 & \pm & $\mathbf{1 0 . 3 6}$ & $\mathbf{1 5 7 2 . 2 3}$ & \pm & $\mathbf{1 0 . 1 9}$ & $* *$ \\
35 & 1701.52 & \pm & $\mathbf{1 5 . 3 4}$ & $\mathbf{2 0 2 7 . 2 3}$ & \pm & $\mathbf{1 3 . 0 2}$ & $* *$ \\
42 & 1949.32 & \pm & $\mathbf{2 0 . 2 8}$ & $\mathbf{2 4 7 8 . 8 6}$ & \pm & $\mathbf{1 5 . 9 6}$ & $* *$ \\
49 & $\mathbf{2 2 5 4 . 5 3}$ & \pm & $\mathbf{2 4 . 6 3}$ & $\mathbf{2 8 6 7 . 4 4}$ & \pm & $\mathbf{1 6 . 4 9}$ & $* *$ \\
\hline
\end{tabular}

** $(\mathbf{P}<0.01)$ season has significant effect

Table 5. Effect of season On weekly and total weight gain (g)

for both sexes of Pekin duck (mean \pm standard error

\begin{tabular}{|cccccccc|}
\hline Period (day) & \multicolumn{5}{c}{ Mean weight gain ( g/ bird/week ) } & $\begin{array}{c}\text { Significant } \\
\text { level }\end{array}$ \\
\hline $1-7$ & \multicolumn{3}{c}{ summer } & \multicolumn{3}{c}{ winter } & $* *$ \\
$8-14$ & $\mathbf{1 6 0 . 4 9}$ & \pm & $\mathbf{2 . 1 3}$ & $\mathbf{1 4 7 . 2 5}$ & \pm & 1.98 & $* *$ \\
$15-21$ & 385.78 & \pm & 4.24 & $\mathbf{3 3 9 . 8 1}$ & \pm & 5.96 & $* *$ \\
$22-28$ & 353.58 & \pm & 6.96 & $\mathbf{5 1 5 . 1 5}$ & \pm & 9.41 & $* *$ \\
$29-35$ & 408.76 & \pm & 6.96 & $\mathbf{5 2 8 . 5 0}$ & \pm & 12.96 & $* *$ \\
$36-42$ & 343.29 & \pm & $\mathbf{8 . 0 9}$ & $\mathbf{4 5 5 . 0 0}$ & \pm & 16.75 & $* *$ \\
$43-49$ & $\mathbf{2 4 7 . 8 0}$ & \pm & $\mathbf{8 . 0 5}$ & $\mathbf{4 5 1 . 6 3}$ & \pm & $\mathbf{2 0 . 3 3}$ & $* *$ \\
Total Peroid & $\mathbf{3 0 5 . 2 0}$ & \pm & $\mathbf{8 . 8 3}$ & $\mathbf{3 8 8 . 5 8}$ & \pm & $\mathbf{2 1 . 8 6}$ & $* *$ \\
\hline
\end{tabular}

** $(\mathbf{P}<0.01)$ season has significant effect 
Iraqi Journal of Agricultural Sciences -2020:51(Special Issue):116-123 AL-Ghabban \& AL-Hassani

Table 6. Effect of sex on mean weekly live body weight (g) of Pekin Duck in summer and winter seasons(mean \pm standard error)

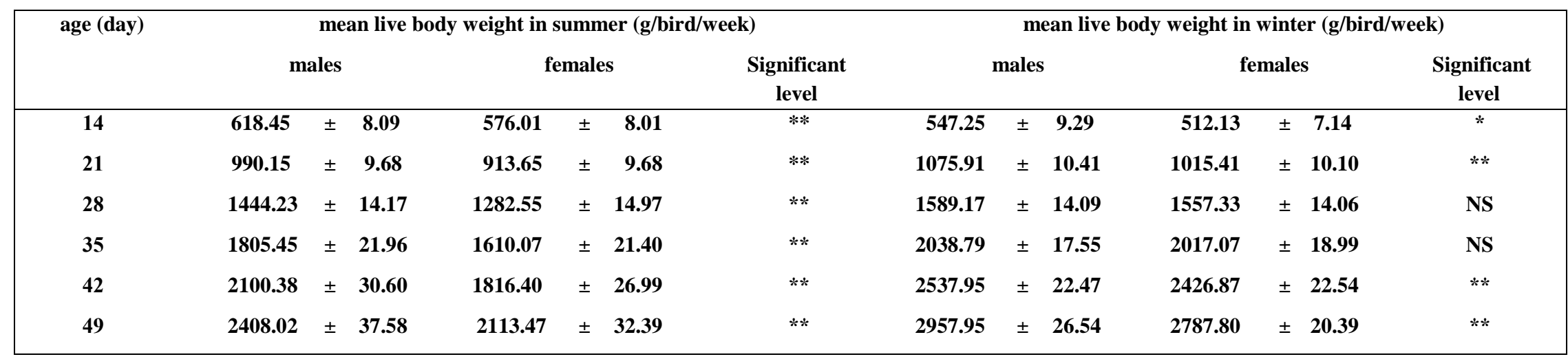

*,** and NS mean sex has significant effect at levels $(\mathrm{P}<0.05)$, (p $<0.01$ ) and no significant effect respectively.

Table7. Effect of sex on mean weekly and total weight gain (g) of pekin duck in summer and winter seasons (mean \pm standard error)

\begin{tabular}{|c|c|c|c|c|c|c|c|c|c|c|c|c|c|}
\hline \multirow{3}{*}{$\begin{array}{l}\text { Age (day) } \\
15-21\end{array}$} & \multicolumn{7}{|c|}{ mean weight gain in summer (g/bird/week) } & \multicolumn{6}{|c|}{ mean weight gain in winter (g/bird/week) } \\
\hline & \multicolumn{3}{|c|}{ males } & \multicolumn{3}{|c|}{ females } & \multirow{2}{*}{$\begin{array}{c}\begin{array}{c}\text { Significant } \\
\text { level }\end{array} \\
* *\end{array}$} & \multicolumn{3}{|c|}{ males } & \multicolumn{2}{|c|}{ females } & \multirow{2}{*}{$\begin{array}{c}\begin{array}{c}\text { Significant } \\
\text { level }\end{array} \\
\text { NS }\end{array}$} \\
\hline & 371.69 & \pm & 6.87 & 337.64 & \pm & 5.83 & & 528.65 & \pm & 14.47 & 503.28 & \pm 12.28 & \\
\hline $22-28$ & 454.07 & \pm & 9.39 & 368.89 & \pm & 10.15 & $* *$ & 513.25 & \pm & 20.17 & 541.92 & \pm 16.68 & NS \\
\hline 29-35 & 361.22 & \pm & 10.91 & 327.52 & \pm & 11.79 & * & 449.62 & \pm & 22.27 & 459.73 & $\pm \quad 24.65$ & NS \\
\hline $36-42$ & 294.92 & \pm & 13.92 & 206.33 & \pm & 10.26 & $* *$ & 499.16 & \pm & 30.87 & 409.80 & $\pm \quad 26.80$ & * \\
\hline 43-49 & 307.63 & \pm & 13.02 & 303.06 & \pm & 12.00 & NS & 420.00 & \pm & 32.42 & 360.93 & $\pm \quad 29.57$ & NS \\
\hline $\begin{array}{c}\text { Total period } \\
(1-49)\end{array}$ & 2358.42 & \pm & 37.58 & 2060.87 & \pm & 32.39 & $* *$ & 2916.45 & \pm & 26.54 & 2746.30 & $\pm \quad 20.39$ & $* *$ \\
\hline
\end{tabular}

*, ** and NS mean sex has significant effect at levels $(\mathrm{P}<0.05),(\mathrm{p}<0.01)$ and no significant effect respectively 
Table 8. Effect of season on mean weekly and total feed consumption (g/bird) in both sexes of pekin duck (mean \pm standard error)

\begin{tabular}{|crrrrrrc|}
\hline Period (day) & \multicolumn{3}{c}{ Mean feed consumption (g/bird/week) } & Significant level \\
& summer & \multicolumn{3}{c|}{ winter } & \\
\hline $1-7$ & 213 & \pm & 11.27 & 189 & \pm & 9.71 & NS \\
$8-14$ & 601 & \pm & 14.68 & 514 & \pm & 18.65 & $*$ \\
$15-21$ & 878 & \pm & 33.04 & 1116 & \pm & 36.95 & $* *$ \\
$22-28$ & 1082 & \pm & 33.40 & 1447 & \pm & 50.07 & $* *$ \\
$29-35$ & 1090 & \pm 37.44 & 1534 & \pm & 52.76 & $* *$ \\
$36-42$ & 1044 & \pm 32.05 & 1716 & \pm & 56.95 & $* *$ \\
$43-49$ & 1277 & \pm 49.36 & 1681 & \pm & 43.75 & $* *$ \\
Total priod & 6185 & \pm 122.12 & 8197 & \pm 160.63 & $* *$ \\
\hline
\end{tabular}

*, ** and NS mean sex has significant effect at levels $(\mathrm{P}<0.05),(\mathrm{p}<0.01)$ and no significant effect respectively.

Table 9. Effect of season on feed conversion ratio in both sexes of pekin duck (mean \pm standard error)

\begin{tabular}{|cccccc|}
\hline Period (day) & \multicolumn{2}{c}{ feed conversion ratio (g feed/ g weight gain) } & Significant level \\
& \multicolumn{2}{c}{ summer } & \multicolumn{2}{c|}{ winter } \\
\hline $1-7$ & 1.33 & \pm 0.07 & 1.28 & \pm 0.08 & NS \\
$8-14$ & 1.56 & \pm 0.12 & $1.51 \quad \pm 0.08$ & NS \\
$15-21$ & 2.48 & \pm 0.09 & 2.17 & \pm 0.12 & $*$ \\
$22-28$ & 2.65 & \pm 0.14 & 2.74 & \pm 0.17 & NS \\
$29-35$ & 3.18 & \pm 0.20 & 3.37 & \pm 0.16 & NS \\
$36-42$ & 4.21 & \pm 0.27 & $3.80 \quad \pm 0.21$ & NS \\
$43-49$ & 4.19 & \pm 0.20 & $4.33 \quad \pm 0.32$ & NS \\
total period & 2.80 & \pm 0.11 & $2.90 \quad \pm 0.13$ & NS \\
\hline
\end{tabular}

* and NS mean sex has significant effect at levels $(P<0.05)$, and no significant effect respectively.

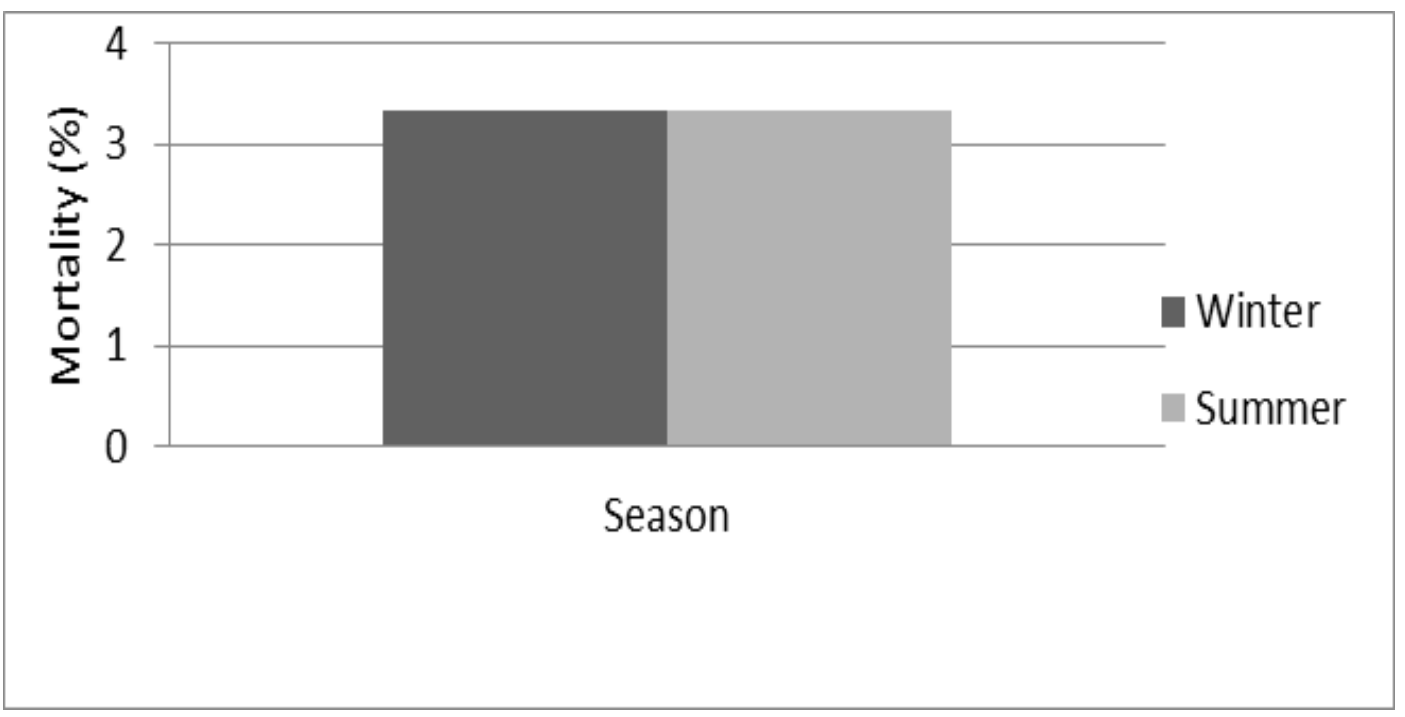

Figure 1. Effect of summer and winter seasons on total mortality of Pekin duck 


\section{REFERENCES}

1. Abdul-latif, K. M., D. H. Al-Hassani and B.G.Al-Khatib. 2002. Effect of supplementation of different levels of vitamin E with drinking water on productive performance and immune response of broiler. Iraqi J. Agric. Sci. (special issue) 7(1) : 48-55. 2. Al-Hassani D.H. and M.H. Abdul-Abaas. 1987. Some physiological and physical characteristics of imported ducks Reared in Iraqi conditions. Iraqi J. Agri. Sci. 18(2): 8391

3. Al-Hassani D.H. and A. Al-Shukri. 2016. Comparative efficacy of different supplements with drinking water used to alleviate body temperature of heat-stressed broiler chickens. Iraqi J. Agri. Sci. 47(Special Issue):12-18 4. Al-Hassani D., B. Saadi, N. Hanash, and H. Alrubaye. 2012. Efficacy of betaine supplemented to diet and sex response to some traits and measurements of broiler (ROSS) chickens reared under heat stress conditions. Alrafidian Agri. J. 40(3):148-155

5. Al-Shukri, A.Y and D.H. Al-Hassani. 2012. Effect of betaine supplemented with drinking water on water intake pattern of broiler chickens exposed to heat stress. Journal of Tikrit University for Agriculture Sciences. 12(2): 107-115

6. Al-Zobaie, R.J.R. 2010. Study the Effect of Hatching Egg Weight on Traits of Fertility, Hatchability and Productive Performance of Broiler Chicken. M.Sc. Thesis, Coll. Agric. Sci., University of Baghdad. pp: 40-41

7. Awad, A. L., H. N. Fahim, A. F. Ibrahim and M. M. Beshara. 2014a. Effect of dietary betaine supplementation on productive and reproductive performance of Domyati ducks under summer conditions. Egypt. Poult. Sci. 34(2): 453-474

8. Awad, A. L., A. F. Ibrahim, H. N. Fahim and M. M. Beshara. 2014b. Effect of dietary betaine supplementation on growth performance and carcass traits of Domyati ducks under summer conditions. Egypt. Poult. Sci., 34(4):1019-1038

9. Basuony, H. A. M. 2011. Effects of Seasonal Variations on Thermoregulation of Ostrish. Ph.D. Dissertation, Coll. Agri., AlAzhar University. Egypt. pp: 57-58
10 Cherry, P. and T. R. Morris. 2008. Domestic Duck Production. Science and Practice. CABi Publishing. pp: 142- 153 11. El-Badry, A. S. O., M. M. Hassanane, E. S. Ahmed and K. H. El-Kholy. 2009. Effect of early-age acclimation on some physiological, immunological responses and chromosomal aberrations in Muscovy ducks during exposure to heat stress. Global Journal of Biotechnology and Biochemistry, 4 (2):152-159

12. Farhat, A. and E. R. Chaves. 2000. Comparative performance, blood chemistry, and carcass composition of two lines of pekin ducks reared mixed or separated by sex. Poul. Sci. 79: 46-51

13. F.A.O. 2017. Food and Agriculture Organization Of The United Nations Statistics Division Database

14. Habeeb, G, R., D. H. Al-Hassani and I.H.Ismail. 2004a. Effect of enzymes supplementation to broiler diet reared under hot climate on some blood traits. Iraqi $\mathrm{J}$. Agric. Sci. 35(4) : 115-120

15. Habeeb, G. R., D. H. Al-Hassani and I. H. Ismail, 2004b. Effect of enzymes supplementation on some productive traits of broiler reared under hot climate. Iraqi J. Agric. Sci. 35(1) : 141-144

16. Hebatallah, E. E., M. M. Sharaf and R. R. Rashed. 2016. The effect of different intervention strategies to alleviate heat stress on behavior, performance and some blood parameters of growing Muscovy ducks. Alexandria Journal of Veterinary Science, 48(2): 69-76

17. Ibrahim, D.K. and D. H. Al-Hassani. 2003. Effect of dewinging on egg production and egg quality of layers reared under moderate and high temperatures in Baghdad. Iraqi J. Agric. Sci. 34(2) : 191-196.

18. Kleczek, K., E. Wilkiewicz-Wawro, K. Wawro and W. Makowski. 2007. Effect of body weight of day-old Muscovy ducklings on growths and carcass traits. Arch. Titrz., 50(2): 204-213

19. Ma, X., Y. Lin, H. Zhang, W. Chen, S. Wang, D. Ruan and Z. Jiang. 2014. Heat stress impairs the nutritional metabolism and reduces the productive of egg-laying ducks. Animal Reproduction Science, 145(4): 182-190

20. Morêki, J.C. 2008. Feeding Strategies in Poultry in Hot Climate. www.gov.bw 
21. N.R.C. 1994. Nutrient Requirements of :http://www.dpi.nsw.gov.au/_data/assets/pdf_ Poultry. Ninth revised edition, 1994. file/0009/442854/introduction-to-commercialhttp://www.nap.edu/catalog/2114.html duck-farming.pdf

22. Pingel, H. 2011. Waterfowl production for 25. Wawro, K., E. Wilkiewicz-Wawro, K. food security. Lohmann Information, 46 (2) : $32-42$

23. SAS. 2012. Statistical Analysis System, User's Guide. Statistical. Version $9.1^{\text {st }}$ Ed. SAS. Inst. Inc. Cary. N.C. USA Kleczek and W. Brzozowski. 2004. Slaughter value and meat quality of Muskovy ducks, Pekin ducks and their crossbreeds, and evaluation of the heterosis effect. Arch. Tierz., 24. Stein B, 2012. Introduction to commercial duck farming, Department of Primary Industries, 